\title{
Formation of a research attitude to the surrounding world in younger schoolchildren
}

\author{
Lyubov Soboleva ${ }^{1, *}$, Elena Morozova ${ }^{1}$ \\ ${ }^{1}$ Saratov State University, Astrachanskay str., 83, 410017, Saratov, Russia
}

\begin{abstract}
The article examines the issue of the development of a research attitude to the surrounding world in younger students. The authors state that there is a contradiction between the need for developing methods of organizing research activities among primary schoolchildren and investigation of such methods. The article offers a model of forming a research attitude to the surrounding world among younger schoolchildren during extracurricular activities The model includes the following blocks: targeting; structural and content-related; operational and activity-related; efficiency evaluating. The model describes a step by step process projected by the teacher and members of the scientific community. It starts with stimulating children's interest in the research of specific social and natural objects of the city park; next comes their mastery of the researcher social roles and, finally, children become aware that a research attitude in organizing meaningful activities helps maintain the status of the city park for the cultural future of the next generations and the advance of domestic science. Addressing the issue of forming a research attitude towards the surrounding world in younger schoolchildren made it possible to work out the questions of developing education and upbringing in primary school from the perspective of cultural norms, as a part of the internal individualization of education, and with regard to the schoolchildren's acquisition of productive reflection on research strategies.
\end{abstract}

\section{Introduction}

The development of the individualization of the educational process, the formation of the subjectiveness of primary schoolchildren are the important tasks of modern education.

According to the new state standard, junior schoolchildren should master different types of academic and research activities. With the assistance of a teacher, children can learn to act effectively in new research situations, draw new knowledge from their own experience, and also put the previously accumulated knowledge and skills in practice. However, in primary education, the research activity of junior schoolchildren often turns into a system of prescriptions, its result is predetermined, therefore, the child's freedom of choice and creative exploration are limited.

In the works of domestic educators and psychologists [8-11], research activity in education is shown as a complex process aimed at ensuring an inextricable connection of

\footnotetext{
* Corresponding author: makarovaluban@mail.ru
} 
emotions, knowledge and actions of students, allowing them to better understand their personal characteristics, to comprehend and to accept the values of research and communication, to master the models of research behavior and creativity. In research activities, particular importance lies with the individual's desire to show their own activity and cognitive independence, to explore the novelty and complexity of the changing world, to create new original strategies of behavior and activity. To develop the research activity of schoolchildren, the need for the development of such personality neo-formations as "research activity", "research interest", "research position", "research initiative", etc. has been substantiated by many authors [4, 9, 12, 13]. The directions of stimulating the investigative search of the student were identified: 1) a specially organized subject-matter action, which allows reaching the representation of the problem in the consciousness of the student, thereby actualizing the need for its solution; 2) emotional charge, identification with a real researcher [1].

Nevertheless, the problems of teaching research activity in primary school are still solved at an external level as compared to the research experience of children, and they are solved through the activity of a teacher, not a student.

We substantiated the concept of "the research attitude of junior schoolchildren to the surrounding world" as an integrative quality of a child's personality, which is formed in the process of realizing the sociocultural essence of research activities, accepting the social role of a researcher, assessing their research capabilities and human achievements, mastering research models of behavior for interacting with objects and subjects of the surrounding world as socio-natural values $[2,3]$.

Addressing this concept allows us to work out the issues of development of education in primary school from the standpoint of cultural norms (whether a child evaluates a research situation adequately to sociocultural norms or selfishly); within the framework of the internal individualization of the educational process (what factors cause the child to have positive emotions for research: interest in the object of research or in research activity itself, the desire to help other people, the desire to advance further than others in achieving the research goal, etc.); taking into account the mastery of productive reflection on research strategies (which research roles can be mastered by children and reveal their personal potentials).

We organized an experimental work with the aim of introducing a model for the formation of a research attitude of younger students to the surrounding world (in extracurricular activities) and identifying its levels of formation.

\section{Materials and methods}

The experimental base of our investigation was secondary school No. 60 in Saratov. The experiment was carried out at the expense of the time allocated for extracurricular activities of children. The experimental sample consisted of 103 junior schoolchildren, 51 of whom made up the experimental group, and 52 - the control group. The experiment included the ascertaining, formative and control stages. The research was carried out in three stages: 1 . Years 2016-2017. Study of the relevant literature; analysis of practical experience on the research problem, identifying the conceptual apparatus, subject, hypothesis, methodology and methods of the scientific apparatus, the empirical base of the research. 2. Years 20172018. Development and practical testing of a set of tasks and a theoretical model of forming a research attitude of primary schoolchildren to the outside world. 3.Years 2018-2019. Analysis, systematization, generalization, and mathematical processing of the research results.

At the ascertaining stage, we studied the initial level of the formation of the research attitude to the surrounding world and the degree of development of its components using a 
questionnaire [2]. Also, we employed "EZOP", the verbal associative methodology for diagnosing the ecological attitudes of a person in relation to nature $[14,15]$. At the formative stage, we introduced our model for the formation of a research attitude towards the surrounding world in younger schoolchildren during their after-class activities. At the control stage, we carried out a repeated diagnostics of the formation of the research attitude to the surrounding world in the experimental and control groups of schoolchildren.

\section{Research results}

The developed model includes targeting; structural and content-related; operational and activity-related; efficiency evaluative blocks.

\subsection{The conceptual basis}

The conceptual basis of the model is formed by cultural, axiological, activity-related and eco-psychological approaches. To achieve the main goal, the following tasks were formulated: the formation of ideas and concepts in younger schoolchildren about the features and variability of the surrounding world, about the possibilities, methods and results of research activities, about the social role of the researcher; about the values of nature and ways of non-pragmatic interaction with it; determining the value-based priorities of the interaction of students with socio-natural objects and assessing the significance of research activities from the cultural standpoint, determining the value-based foundations in setting goals, in choosing the means, forms, methods of research activities, in assessing the quality of the result of research activities; encouraging junior schoolchildren to an independent investigative search for interaction with objects and subjects of the world around them as socio-natural values and solving the assigned tasks using research methods.

\subsection{The structural and content-related block}

The structural and content-related block is focused on the development of the components of the relationship under consideration. The emotional-evaluative component embraces emotions, feelings, value-based judgments in relation to objects of research and elements of research activities. The cognitive component is realized in the course of the development of ideas and concepts about the natural and social objects of the surrounding world, the possibilities, methods and results of research activities, about the social (moral and ethical) role of the researcher, the cognitive interest in the process and the subject of research, which makes it possible to comprehend the sociocultural essence of the research activity in modern society. The activity-related component includes motives and needs of interaction with objects of the surrounding world as socio-natural values; skills and abilities of a subject and supra-subject nature for solving a research problem: modeling the image of the park of the future. The educational and formative process of the proposed model is based on two central concepts: 1) a park as a significant socio-natural system of the surrounding world, in which the creatures of nature play a leading role; a park as an important element of the ecological framework of Saratov city and the Saratov region); 2) the activity of a researcher as a person who contributes to the acquisition of new knowledge and valuebased ideas in specific areas of human activity. 


\subsection{Operational and activity-based block}

We used a set of methods, techniques, instruments of teaching and upbringing: research situations, emotional value-based situations, methods of introducing a child to real research interaction, methods of individual and group work, etc. An important role in the organization of research activities of younger schoolchildren was played by excursions to Saratov city park within the framework of the regional project "Mysteries of the City Park, or the Secret of Governor A.D. Panchulidzev " [5-7]. The model includes a staged process designed by the teacher and members of the scientific community: stimulating children's interest in research actions with specific social and natural objects of the city park, their mastering the social roles of a researcher, students' awareness of the possibility of manifesting a research attitude in organizing research activities to maintain the nature of the city park for the cultural future of the following generations and advance of the national science.

\subsection{Within the framework of the efficiency evaluative block}

We carried out the study of the level of formation of the research attitude to the surrounding world with regard to the degree of development of its components.

The results of the ascertaining experiment made it possible to reveal that a significant part of primary schoolchildren $57 \%$ of the experimental group and $58 \%$ of the control group) demonstrate a low level of formation of the research attitude towards the surrounding world. The acceptable level of research attitude is presented in $41 \%$ of the respondents in the experimental and $39 \%$ of the respondents in the control group. The optimal level of research attitude is presented in $2 \%$ and $3 \%$, respectively, of students in the experimental and control groups. In children of primary school age, there is an uneven development of the components of the research attitude: cognitive (30\% in the experimental and $29 \%$ in the control group), emotional-evaluative (25\% and $26 \%$, respectively) and activity-related (18\% in the experimental and $18 \%$ in the control group). In most cases, junior schoolchildren have limited ideas about the social role of the researcher, the effectiveness and possibilities of such work. They are not sufficiently prepared to independently formulate various research goals, to obtain a variety of research results and their further use, to a moral assessment of their own research actions. The ranking according to the results of the EZOP diagnostics showed that the pragmatic attitude dominates: "nature as an object of benefit" (33\% and 31\%, respectively) and the aesthetic attitude "nature as an object of beauty" (32\% in the experimental group and $30 \%$ in the control group), the attitude "nature as an object of study" (cognitive attitude) (21\% and $20 \%$, respectively) and ethical "nature as an object of protection" (14\% and 19\%, respectively).

\section{Discussion of the results}

At the formative stage, the development of a research attitude to the world around in younger schoolchildren was carried out as a result of the introduction of a model of its formation.

\subsection{Stage "Park of Secrets and Mysteries"}

The main directions of its implementation: 1. To reveal the emotional and personal attitude of schoolchildren to the object of research (the city park as a socio-natural object) and to research activities. 2. To develop knowledge and value-based judgments of students about 
nature (about the park), about the elements of people's research activities. 3. To help schoolchildren comprehend the exploratory actions of a significant fairytale character.

In order to enhance the value and attractiveness of research activities, we organized excursions to the park during which they together with the teacher performed individual and group tasks: "Secrets of Coniferous Plants"; "Autumn and Winter Secrets of the Park Trees"; "Animal Paths; "Map of the Sounds of Nature"; "Colors of Nature", "The Secret of the Old Oak", "The Work of the Wind", "Squirrels' Secrets", "Where Do Stumps Come From?" and others. Schoolchildren mastered the basics of organizing and recording research results. In out-of-class activities, the children discussed the questions "Who is a researcher?", "What goals and objectives are set by modern researchers, how are they achieved?" The multifaceted activities of researchers - experimenters, researchers creators, researchers - generators of ideas in the history of our state and region were discussed. The children created a map "Secrets of the City Park" and put down the symbols of the park's natural objects on a sheet of paper. The game "Who is in the chief in the park?" helped to solve questions about interconnections in nature. We discussed the needs of the inhabitants of the park, which are violated through human fault. We outlined the ways of research work in the park involving some fairy-tale characters.

\subsection{Stage "Park of Good Deeds"}

The main directions of work: 1. To develop knowledge and value-based judgments of students about the city park as an important element of the ecological framework of Saratov, to get involved in assessing its ecological state; 2 . To ensure the child's acceptance of the social role (researcher-historian, researcher-sociologist, researcher-ecologist) associated with research activities, which presupposes high educational and research motivation of the park protector. 3. To facilitate students' assessment of their research capabilities and awareness of their needs in interaction with the inhabitants of the park.

The subject of the collective research was identified while building up an emotional situation in the course of reading a letter of Saratov region governor A.D. Panchulidzev from the distant past. The work of the children was organized in the groups "researchers sociologists", "researchers - historians", "researchers - ecologists". The results of the work of students from the group "researchers - sociologists" made it possible to reveal that the park played an important cultural role in the life of our region. At the present stage, most of the park's visitors positively assess its redevelopment and landscaping. However, not many city residents take an active part in improvement and greening of the park and the city. We started to study the diverse activities of people in the park: environmental, healthpreserving, research, entertaining, career guiding, patriotic, aesthetic, recreational, practiceoriented, etc.

The actions of the children from the group "researchers - historians" made it possible to understand that the structure of the old park and the modern one differ significantly from each other: the number of green areas has decreased, the social and play areas of the park have significantly expanded.

The results of the work of the children from the group "researchers - ecologists" helped to realize that the natural heritage of the park is enormous and must be protected. The students revealed contradictions between park authorities' and environmental organizations views on the development of the park The administration proposes to significantly expand the infrastructure of the park: fill up the ponds, set up cafes, build a skating rink, provide parking lots, etc. The children and environmentalists examined the territory of the city park and came to the conclusion that two-hundred-year-old oaks are drying up, the hydrological regime of ponds is broken, channels and springs feeding the ponds are clogged, residential buildings are too close to the park, certain areas are heavily littered, etc. The children made 
important conclusions: people will take care of the park if the cultural functions of the park continue to develop; it is our duty to preserve the unique oak forest together with the ponds; plants alongside with other inhabitants may participate in the development of the park.

\subsection{Stage "Park of the Future"}

The main directions of work: 1 . To include the direction of individual research chosen by the child in the context of research activity that is significant both for him and the team. 2 . To ensure that schoolchildren show initiative in generating a program of research and nature conservation projects for the improvement of the park, the development of its cultural, historical and environmental potentials. 3. To develop the moral motives of the researcher's sense of duty and responsibility for the future of the park and the cultural future of future generations. The children's suggestions for the improvement of the park's territory helped to organize the "Fair of Research Projects". The children presented their own models of the park of the future. Among them were School park; Memory Park; Health Park; Park of Games and Natural Quizzes; The Park as an Open-Air Laboratory; Family Traditions Park; Beauty Park; Park of Unique Plants, Park of Professions; Our Park As the History of the city; Park of nature smells and sounds. Park Inside the School is Possible! Park as a Green Path to the future! An important outcome of children's projects was their independent formulation of burning issues for further study of the park, namely: Are there any champions among the park's plants? Plants heal us, should we heal the plants? Do plants need rest? What do we learn from the plants in the park? Is there a friendship between the plants in the park? How does the park breathe? Does the park have its own scent? How to reduce the amount of garbage in the park? Does the city have an ecological framework? How to restore the hydrological regime of the city park ponds?

\section{Conclusions}

Diagnostics of the level of formation of the research attitude of younger schoolchildren to the surrounding world at the control stage of the experiment showed that a significant part of younger schoolchildren (61\% of the control group) still demonstrate a low level of formation of the studied indicator, while in the experimental group the figure dropped to $27 \%$. The admissible level of the formation of the research attitude of junior schoolchildren to the world around them is presented in $62 \%$ of the respondents in the experimental and $36 \%$ of the respondents in the control group. The indicators of the optimal level were $11 \%$ and $3 \%$ (of the experimental and control groups, respectively), which demonstrates significant changes in the formation of the research attitude to the surrounding world in the children of the experimental group and the success of the implemented model of the formation of the research attitude in younger schoolchildren to the outside world during extracurricular activities. Ranking based on "EZOP", a verbal associative methodology for diagnosing the ecological attitudes of a person developed by V.A. Yasvin showed that younger students expanded not only cognitive, but also aesthetic and ethical attitudes in the experimental group. The attitude "nature as an object of benefit" (pragmatic attitude) is present in the answers of only some children.

Study of the psycho-didactic aspects of organizing educational and research activities of junior schoolchildren allowed us to comprehend the importance of coordinating the research attitude to surrounding the world and the choice of the child's social role of the researcher, assuming high educational and cognitive motivation and research initiative; schoolchildren's awareness of the significance of their research needs in interaction with the inhabitants of the park and members of the scientific community; the schoolchildren' $s$ 
experiences of the moral sense of duty and responsibility of the researcher for the future of the park and the cultural heritage of future generations.

\section{References}

1. S.L. Belykh, Moscow Narodnoye Obrazovanie 3, 68-74 (2006)

2. L.N. Makarova, E.E. Morozova, Siberian pedagogical journal 2, $45-50$ (2018) https://doi.org/10.15293/1813-4718

3. L.N. Makarova, Saratov University Bulletin. Series Acmeology of Education. Developmental psychology 4(32), 374-378 (2019) https://doi.org/10.18500/2304-97902019-8-4-374-378

4. G.V. Makotrova, Domestic and foreign pedagogy 2, 141-150 (2016) https://doi.org/10.24411/2224-0772

5. E.E. Morozova, O.A. Isaeva, Ecological and civil project "Secrets of the City Park". Textbook for primary and secondary school students (Nauka, Saratov, 2016)

6. E.E. Morozova, O.A. Isaeva, Yu.V. Volkov, T.V. Nikeshina, L.N. Makarova, Ecological project "Secrets of the City Park". Textbook for students of educational institutions (Nauka, Saratov, 2018)

7. E.E. Morozova, I.V. Rudenko, N.P. Nikinova, O.I. Vaganova, Z.V. Smirnova, N.Y. Belova, International Journal of Recent Technology and Engineering 8(1), 1719-1722 (2019)

8. A.S. Obukhov, School technology 5, 86-90 (2006)

9. A.N. Poddyakov, School technology 3, 85-89 (2006)

10. A.I. Savenkov, Research teaching methodology for primary schoolchildren (Uchebnaya Literatura, Samara, 2004)

11. A.I. Savenkov, A.S. Lvova, O.A. Lyubchenko, L.E. Osipenko, Bulletin of the Moscow city pedagogical University. Series: Pedagogy and psychology. Moscow city pedagogical University 2(36), 54-61 (2016) https://doi.org/10.25688

12. N.B. Shumakova, Primary school plus before and after 10, 3 - 9 (2006)

13. N.B. Shumakova, N.I. Avdeeva, E.V. Klimanova, Development of research skills of primary schoolchildren (Enlightenment, Moscow, 2011)

14. V.A. Yasvin, Psychology of relationship to nature (Smysl, Moscow, 2000)

15. V.A. Yasvin, Izvestiya Saratovskogo universiteta. New series. Series: Philosophy. Psychology. Teacherska. Saratov national state University named after N.G. Chernyshevsky 18(1), 80-90 (2018) https://doi.org/10.18500 / 1819-7671-2018-18-180-90 